\title{
Hubungan Kausal Antar Faktor-Faktor Yang Mempengaruhi Sistem Informasi Akademik (Studi Kasus pada Perguruan Tinggi Swasta di Jawa Tengah)
}

\author{
Ahmad Rois Syujak*, Ridho Rahmadi, Yudi Prayudi \\ Program Studi Magister Teknik Informatika, Fakultas Teknologi Industri, Universitas Islam Indonesia Yogyakarta \\ *ahmad.rois.syujak@gmail.com
}

\begin{tabular}{l} 
Info Artikel \\
\hline Kata Kunci : \\
hubungan kausal antar faktor, \\
faktor kualitas, faktor keamanan, \\
sistem informasi akademik \\
Keywords : \\
causal relationships factors, \\
quality factors, security factors, \\
academic information systems \\
Tanggal Artikel \\
Dikirim : 10 Maret 2020 \\
Direvisi : 2 April 2020 \\
Diterima : 11 Mei 2020
\end{tabular}

\section{Abstrak}

Pemanfaatan teknologi informasi tidak hanya pada pemanfaatan sektor bisnis, tetapi juga sektor publik yang salah satunya adalah lembaga perguruan tinggi melalui Sistem Informasi Akademik. Efisiensi dan efektifitas proses informasi dengan menggunakan sistem informasi hanya akan terjadi apabila teknologi tersebut terjamin kualitas serta keamanannya. Studi ini membahas tentang hubungan kausal antar faktor-faktor yang merepresentasikan kualitas dan keamanan Sistem Informasi Akademik pada Perguruan Tinggi. Sejumlah 147 responden ikut berpartisipasi dalam penelitian ini. Dalam memodelkan hubungan kausal, penelitian ini menggunakan sebuah metode baru yang bernama Stable Spesification Search for Cross-Sectional Data with Latent Variable (S3C-Latent) [1]. Dari studi ini, peneliti menemukan hubungan asosiasi antara variabel yang arah kausalnya belum dapat ditentukan dari data kuisioner yang telah didapatkan. Sehingga dalam studi ini menyimpulkan bahwa ditemukan adanya hubungan asosiasi yang kuat yang tidak bisa ditentukan arah hubungan kausalnya. Kualitas sistem informasi sebagai variabel inti berhubungan langsung dengan variabel kualitas informasi. Secara tidak langsung variabel kualitas sistem informasi melalui variabel kualitas informasi mempunyai hubungan dengan variabel kepuasan pengguna, yang mana variabel kepuasan pengguna berhubungan langsung dengan dua variabel lainya yaitu variabel keamanan dan variabel penanganan sistem terhadap masalah keamanan. Hubungan-hubungan tersebut secara umum sesuai dengan studi-studi sebelumnya yang relevan.

\section{Abstract}

The use of information technology is not only in the business sector but also in the public sector, one of which is an academic institution through its Academic Information System. The efficiency and effectiveness of information systems will only succed if the quality and safety of the systems is guaranteed. This Study analyzed the causal relationship between the factors that represent the quality and security of Academic Information Systems in Higher Education. A total of 147 respondents participated in this study. In modeling causal relationships, we use a new method called Stable Specification Search for Cross-Sectional Data with Latent Variables, or abbreviated S3C-Latent [1]. From this study, we found association between variables whose causal direction could not be determined from the questionnaire data that had been obtained. Information system quality as a core variable is only directly related to information quality variable. The information system quality variable through the information quality variable has a relationship with the user satisfaction variable indirectly, where the user satisfaction variable is directly related to two other variables, namely the security variable and the system handling variable to the security problem. The aforementioned associations are consistent with those of previous studies. 


\section{PENDAHULUAN}

\subsection{Latar Belakang}

Globalisasi merupakan perubahan secara internasional yang integrative, yang berdampak pada perkembangan dan pertukaran berbagai produk, jasa, pemikiran, dan lain sebagainya. Globalisasi adalah sesuatu yang tidak terelakkan. Dewasa ini hampir semua sektor di kehidupan telah mengalami perkembangan, terlebih dalam dunia teknologi dan komunikasi. Semua yang berkaitan dengan teknologi dan komunikasi semakin berkembang cepat.

Perkembangan teknologi ini memberikan kemudahan untuk mengakses informasi secara cepat dan dengan biaya murah yang disediakan oleh website itu sendiri. Pada saat ini banyak di antara perguruan tinggi yang menggunakan teknologi web untuk melayani mahasiswa dalam bidang akademik[2]. Salah satu pemanfaatan teknologi web adalah dalam bentuk Sistem Informasi Akademik yang saat ini telah menjadi salah satu infrastruktur utama pada perguruan tinggi.

Dalam dunia pendidikan, kebutuhan sistem informasi dapat diartikan sebagai kemampuan, syarat atau kriteria yang harus ada atau dipenuhi oleh sistem informasi, sehingga apa yang diinginkan pemakai dari sistem informasi dapat diwujudkan. Sistem informasi akademik, sudah banyak digunakan oleh hampir semua perguruan tinggi di Indonesia khususnya, hal ini dimaksudkan untuk mempermudah penyampaian informasi kepada peserta didik, tenaga pengajar maupun tenaga administrasi dalam pengelolaannya. Semakin banyak interaksi antara sistem dan pengguna maka sistem akan menjadi rentan untuk disusupi atau dirusak oleh pihak-pihak yang tidak bertanggung jawab.

Keamanan informasi merupakan salah satu aspek penting yang harus diperhatikan oleh organisasi dan perusahaan. Kebocoran, kerusakan atau hilangnya suatu informasi dapat menimbulkan kerugian baik secara finansial maupun produktivitas bagi organisasi dan perusahaan. Pada awalnya, keamanan informasi berpijak pada tiga prinsip yaitu: confidentiality, integrity, dan availability (CIA). Tetapi seiring perkembangan teknologi informasi, prinsip itu dikembangkan menjadi ClA+, yaitu confidentiality, integrity, availability, privasi, identification, authentification, authorization, dan accountability. Keamanan data/informasi secara langsung maupun tidak langsung dapat mempertahankan kelangsungan proses bisnis, mengurangi risiko, dan bahkan mendorong meningkatnya peluang bisnis. Ancaman dan risiko yang ditimbulkan akibat kegiatan pengelolaan dan pemeliharaan data/informasi menjadi alasan disusunnya standar sistem manajemen keamanan informasi yang di antaranya adalah ISO 27001 [3].

Masalah keamanan [4] merupakan salah satu aspek penting dari sebuah sistem informasi. Terjadinya masalah keamanan dapat menimbulkan kerugian bagi organisasi, misalnya, kerugian apabila sistem informasi tidak bekerja selama kurun waktu tertentu, kerugian apabila ada kesalahan data atau informasi dan kehilangan data. Sementara itu, selama penerapan aplikasi sistem informasi akademik ini telah terjadi beberapa permasalahan antara lain sering ditemukan terjadinya kebocoran informasi pada karyawan yang tidak berhak atas informasi tersebut dan hal tersebut dapat mengancam kerahasiaan organisasi. Selain itu, dikhawatirkan dapat merambat pada terjadinya penyalahgunaan informasi yang merugikan organisasi dalam persaingan dengan para kompetitor. Kendala lain yang ditemukan adalah kerusakan peralatan yang berhubungan dengan sistem informasi yang dapat menyebabkan hilangnya data perusahaan atau sistem yang berhenti. Masalah keamanan merupakan salah satu aspek penting dari sebuah sistem informasi bagaimana penyusup dapat masuk kedalam sistem melalui jaringan yang tersedia.

Salah satu cara untuk memahami kualitas dan keamanan sistem informasi adalah dengan memahami mekanisme kausal antara faktor-faktor yang representatif. Sebuah model kausal merepresentasikan hubungan sebab-akibat antara faktor-faktor tersebut. Secara teknis, banyak pendekatan pemodelan kausal (Causal Modeling) yang telah dikembangkan dalam beberapa dekade terakhir [1]. Pendekatan kausal tersebut pada prinsipnya dapat dibagi menjadi dua kelompok. constraint-based dan score-based. Constraint-based approach mencari hubungan sebab-akibat dengan menggunakan konsep probabilitas conditional independency (independensi bersyarat) dan aturan orientasi [5]. Score-based approach memberi nilai atau skor (model fitness) model-model kausal dan memilih yang terbaik [1]. Biasanya, skor sebuah model didasarkan pada dua kriteria: seberapa akurasi model merepresentasikan data dan seberapa sederhana struktur model diestimasi. Baik dalam constraint-based maupun score-based, estimasi kausal seringkali semata-mata didasarkan pada estimasi tunggal yang dikenal tidak stabil; sedikit perubahan pada data dapat menyebabkan model yang disimpulkan sama sekali berbeda.

Dalam artikel [6] memperkenalkan sebuah metode baru yang untuk memodelkan hubungan kausal antar faktorfaktor, yang bernama Stable Spesification Search for Cross-Sectional Data with Latent Variable (S3C-Latent). S3C-Latent adalah metode pemodelan kausal antara faktor (variabel laten) yang mengkombinasikan konsep pemilihan stabilitas dan optimasi multi-objektif untuk mencari struktur kausal yang terbaik.

Dalam paper [7] S3C dirancang untuk memodelkan hubungan sebab akibat antara variabel yang diamati. Yang selanjutnya S3C ini diperluas menjadi S3C-Latent, untuk memodelkan hubungan kausal antara variabel laten. Secara khusus, S3C-Latent menggunakan representasi SEM dengan variabel laten. SEM dengan variabel laten terdiri dari model 
struktural yang mewakili hubungan sebab akibat antara variabel laten, dan model pengukuran yang mewakili hubungan dari laten ke variabel yang diamati. Dalam literatur, variabel laten sering disebut faktor, dan variabel yang diamati sering disebut indikator, variabel manifes, atau proxy.

Dalam penelitian ini, peneliti mencoba mencari dan mempelajari hubungan kausal antar faktor-faktor yang mempengaruhi terhadap sistem informasi akademik. Lewat penelitian ini, peneliti berharap untuk dapat mengetahui kelemahan-kelemahan sistem yang menjadi penyebab permasalahan keamanan informasi yang selama ini terjadi. Selain itu, penelitian ini juga dapat mengukur seberapa jauh kualitas sistem informasi yang dimiliki pihak perguruan tinggi.

\subsection{Literature Review}

\section{Tabel 1. Literature Review}

\begin{tabular}{|c|c|c|c|}
\hline No & Paper & Masalah & Pemecahan Masalah \\
\hline 1. & [2] & $\begin{array}{l}\text { Analisis terhadap manajemen risiko pada } \\
\text { sistem informasi akademik dengan metode } \\
\text { Octave Allegro, pada penelitian ini memaparkan } \\
\text { bagaimana pentingnya akan suatu keamanan } \\
\text { informasi bagi suatu organisasi }\end{array}$ & $\begin{array}{l}\text { Metode octave allegro adalah sebuah } \\
\text { pendekatan yang digunakan untuk menilai } \\
\text { kebutuhan keamanan informasi organisasi }\end{array}$ \\
\hline 2. & [8] & $\begin{array}{l}\text { bahwa melalui kerangka kerja NIST SP } 800-300 \\
\text { Penilaian terhadap suatu sistem informasi } \\
\text { dapat dilakukan melalui } 3 \text { tahap yaitu penilaian } \\
\text { risiko, peringanan risiko dan evaluasi risiko }\end{array}$ & $\begin{array}{l}\text { untuk mengurangi risiko yang akan terjadi pada } \\
\text { sistem informasi, dengan menggunakan } \\
\text { kerangka kerja NIST SP 800-300 dapat } \\
\text { mendeskripsikan profil resiko yang dapat } \\
\text { mengancam keberlangsungan sistem informasi }\end{array}$ \\
\hline 3. & [9] & $\begin{array}{l}\text { memberikan sebuah gambaran mengenai } \\
\text { sistem informasi terkait dengan keamanan } \\
\text { informasi, dimana informasi merupakan aset } \\
\text { penting yang harus dilindungi keamanannya } \\
\text { dari pihak yang tidak berwenang yang akan } \\
\text { menggunakannya untuk kepentingan tertentu } \\
\text { atau akan merusak informasi tersebut }\end{array}$ & $\begin{array}{l}\text { Metode yang digunakan dalam penelitian ini } \\
\text { adalah menggunakan Metode Failure Mode and } \\
\text { Effects Analysis (FMEA) }\end{array}$ \\
\hline 4. & [10] & $\begin{array}{l}\text { Pada penelitian ini dijelaskan tentang proses } \\
\text { pemeriksaan mengenai keamanan informasi } \\
\text { sebagai bagian dari indikator penting dalam } \\
\text { menjaga sebuah sistem informasi }\end{array}$ & $\begin{array}{l}\text { dalam pengembangan dan pemeliharaan } \\
\text { sistem informasi perlu adanya prosedur untuk } \\
\text { memeriksa keabsahan dari penggunaan sistem } \\
\text { informasi akademik dari kerusakan ataupun } \\
\text { kesalahan pengolahan data }\end{array}$ \\
\hline 5. & [11] & $\begin{array}{l}\text { menyimpulkan bahwa kesalahan user / } \\
\text { pengguna adalah salah satu faktor utama } \\
\text { terhadap sebuah risiko keamanan sistem } \\
\text { informasi jika tidak dikelola dan dikendalikan } \\
\text { sebagaimana mestinya }\end{array}$ & $\begin{array}{l}\text { mengkaji beberapa teori dan model untuk } \\
\text { mengembangkan kerangka penelitian dengan } \\
\text { tujuan untuk mengidentifikasi faktor-faktor } \\
\text { yang mungkin mempengaruhi perilaku } \\
\text { kepatuhan pengguna terhadap keamanan } \\
\text { informasi }\end{array}$ \\
\hline 6. & $\begin{array}{l}\text { Penelitian } \\
\text { yang } \\
\text { dilakukan }\end{array}$ & $\begin{array}{l}\text { Penelitian ini bertujuan untuk mencari adanya } \\
\text { hubungan kausal antar faktor-faktor keamanan } \\
\text { dan kualitas Sistem Informasi Akademik }\end{array}$ & $\begin{array}{l}\text { Dengan menggunakan metode baru Stable } \\
\text { Spesification Search for Cross-Sectional Data } \\
\text { with Latent Variable (S3C-Latent) yang } \\
\text { dikembangkan oleh [6] diharapkan } \\
\text { menghasilkan data yang lebih stabil dan akurat. }\end{array}$ \\
\hline
\end{tabular}

\subsection{Tujuan dan Manfaat Penelitian}

Adapun tujuan dan manfaat penelitian ini adalah untuk mengetahui dan mengidentifikasi faktor-faktor apa saja yang mempengaruhi Sistem Informasi Akademik serta hubungan antar faktor-faktor yang mempengaruhi Sistem Informasi Akademik. Dan juga memberikan model kausal yang dapat membantu evaluasi serta pengembangan Sistem Informasi akademik tersebut. 


\section{METODE PENELITIAN}

Bagian ini mejelaskan metode yang dilakukan dalam penelitian, dimulai dari gambaran umum mengenai alur penelitian, perancangan penelitian, hingga teknik yang digunakan dalam melalukan pengolahan dan analisis data. Perancangan penelitian meliputi perancangan populasi dan sample, model, variabel dan indikator serta teknik pengumpulan data penelitian.

\subsection{Desain Sistem Informasi Akademik}

Studi ini menggunakan sistem informasi akademik (SIAKAD) yang sudah ada pada masing-masing perguruan tinggi, SIAKAD yang digunakan merupakan akses utama untuk mengatur segala urusan perkuliahan dan hal-hal lainnya yang berkaitan dengan akademik.Sistem informasi akademik ini merupakan salah satu pelayanan publik bagi dosen, mahasiswa, dan karyawan guna mempertingkat kinerja mereka. Sistem informasi akademik mempunyai komponen yang sama dengan sistem informasi lainnya. Komponen sistem informasi yaitu hardware, software, data, prosedur, dan manusia.

Sistem infromasi akademik yang dimaksud adalah sistem pengolahan data yang berhubungan dengan proses belajar mengajar perguruan tinggi antara lain: pengolahan data mahasiswa, mata kuliah, data dosen, data nilai, kelas dan juga sistem untuk penyimpanan data dan persiapan dokumen untuk membantu dalam pengambilan keputusan, sebagaimana desain dari modul yang tersedia dalam sistem informasi akademik.

Dalam penggunaan sistem informasi akademik, ada beberapa aktor yang terlibat dalam proses pengolahan data. Sistem informasi akademik mendefinisikan pengguna dalam 4 level, yaitu: Administrator, Karyawan, Dosen dan Mahasiswa. Sedangkan karyawan sendiri terbagi menjadi 6 jenis, yaitu: Staff, PMB, Kepala Akademik, Staff Akademik atau Administrasi, Kepala Keuangan, serta Staff Keuangan.

Masing-masing level memiliki hak akses yang berbeda. Hak akses terhadap modul-modul juga dibatasi pada level pengguna yang bersangkutan. Sebelum pengguna dapat menggunakan, pengguna memiliki hak akses dengan username dan password yang sudah dibuatkan oleh pengelola sistem informasi akademik

\subsection{Alur Proses Penelian}

Gambar 1 merupakan metode penelitian yang menjelaskan alur dan tahapan-tahapan yang dilakukan dalam penelitian ini :

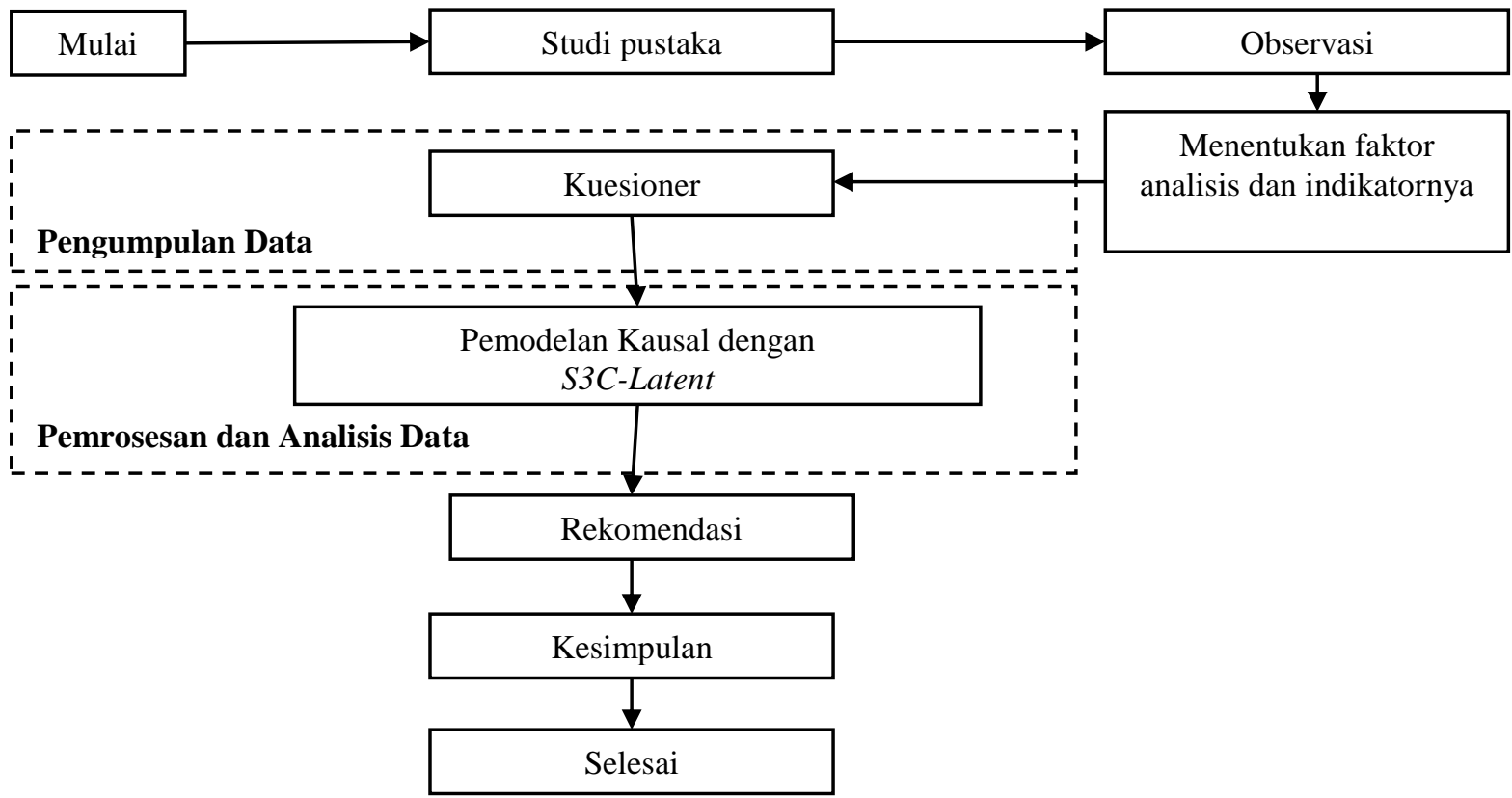

Gambar 1. Alur Penelitian 


\subsubsection{Pemodelan Kausal dengan S3C-Latent}

Menurut [7] S3C dirancang untuk memodelkan hubungan sebab akibat antara variabel yang diamati. Yang selanjutnya S3C ini diperluas ke S3C-Latent, untuk memodelkan hubungan kausal antara variabel laten. Secara khusus, S3C-Latent menggunakan representasi SEM (Structural Equation Modelling) dengan variabel laten. SEM dengan variabel laten terdiri dari model struktural yang mewakili hubungan sebab akibat antara variabel laten, dan model pengukuran yang mewakili hubungan dari laten ke variabel yang diamati. Dalam literatur, variabel laten sering disebut faktor, dan variabel yang diamati sering disebut indikator, variabel manifes, atau proxy.

Parameter SEM hanya dapat diestimasi ketika apa yang disebut kondisi identifikasi terpenuhi. Untuk kedua SEM yang diamati dan SEM dengan variabel laten, kondisi umum adalah bahwa jumlah parameter untuk estimasi sama dengan atau kurang dari jumlah elemen. Secara khusus, SEM dengan variabel laten memiliki kondisi identifikasi tambahan setidaknya ada tiga atau lebih indikator per variabel laten dan Setiap baris $\Lambda_{X}$ dan $\Lambda_{Y}$ hanya memiliki satu elemen bukan nol, sedangkan indikator tidak dapat memuat pada beberapa variabel laten.

Pada awalnya S3C dirancang untuk memodelkan hubungan kausal antar variabel yang di amati (observed variables). Dalam perkembanganya S3C dikembangkan menjadi S3C-Latent untuk memodelkan hubungan kausal antar variabel laten (latent variables). Ide dasar dari $S 3 C$ adalah untuk mencari hubungan antar variabel melalui banyak model yang mungkin, tidak ada batasan yang melarang variabel $X$ dalam satu model menjadi $Y$ pada model lain atau sebaliknya. Kondisi yang sama juga pada indikator yang sesuai, yaitu, $I_{1}$ dalam satu model dapat menjadi $I_{2}$ dalam model lain atau sebaliknya.

Dalam praktiknya, pengetahuan sebelumnya tentang domain yang diminati mungkin ada, misalnya, hasil penelitian sebelumnya yang mengarah pada kendala pada hubungan sebab akibat tertentu. Sebagai contoh, berdasarkan penelitian sebelumnya pada pasien dengan kelelahan, secara medis yang tidak dapat dijelaskan, diketahui bahwa aktivitas fisik secara objektif tidak mengurangi tingkat kelelahan secara langsung. Dalam hal ini SEM with Latent Variable, menjelaskan bahwa pengetahuan sebelumnya ini dapat diterjemahkan ke dalam model struktural dengan variabel laten $X$ (menunjukkan aktivitas fisik objektif) ke variabel laten $Y$ (menunjukkan tingkat kelelahan). Perhatikan bahwa jalur terarah dari $X$ ke $Y$ masih diizinkan, misalnya, Jalur $X \rightarrow \ldots \rightarrow Y$ dengan variabel laten di antaranya. S3C dan S3C-Latent memungkinkan untuk penggabungan pengetahuan sebelumnya tersebut [1].

\subsection{Pengumpulan Data}

\subsubsection{Kuesioner}

Dalam penelitian ini, pembuatan kuesioner dibuat setelah didapatkan indikator - indikator yang sesuai. Setelah didapatkan indikator yang sesuai kemudian kuesioner dipilih disesuaikan dengan penelitian ini. Adapun indikator di ambil dari beberapa penelitian sebelumnya yang sesuai dengan studi ini. Hasil dari kuesioner awal yang peneliti buat kemudian dibuatkan pilot study untuk mendapatkan kuesioner akhir yang bisa dimengerti oleh responden

Kuesioner atau angket merupakan alat pengumpulan data berupa serangkaian pertanyaan yang diajukan kepada responden. Kuesioner dapat dibedakan atas beberapa jenis tergantung dengan sudut pandang tertentu. Dipandang dari cara menjawab, maka dapat dibedakan menjadi kuesioner terbuka dan tertutup. Kuesioner terbuka, kuesioner yang memberikan kesempatan kepada responden untuk menjawab dengan kalimatnya sendiri. Kuesioner tertutup. Kusioner yang sudah menyediakan jawabannya sehingga responden tinggal memilih jawabannya yang ia anggap sesuai.

Dalam penelitian ini penulis menggunakan Kuesioner tertutup dengan menggunakan skala likert. Skala Likert merupakan skala yang digunakan untuk mengukur persepsi, sikap atau pendapat seseorang atau kelompok mengenai sebuah peristiwa atau fenomena sosial, berdasarkan definisi operasional yang telah ditetapkan oleh peneliti. Sewaktu menanggapi pertanyaan dalam skala Likert, responden menentukan tingkat persetujuan mereka terhadap suatu pernyataan dengan memilih salah satu dari pilihan yang tersedia. Salah satu contohnya adalah skala likert dengan 5 level mulai Sangat tidak setuju (1) hingga sangat setuju (5)

Apabila data yang diperoleh melalui jawaban kuesioner telah terkumpul maka angka dalam bentuk skala likert akan dikalkulasikan kemudian akan dianalisis lebih lanjut.

\subsubsection{Metode Pengumpulan Data}

Metode pengumpulan data yang akan penulis lakukan adalah dengan cara menyebarkan kuesioner secara langsung kepada responden dengan memanfaat fasilitas internet dengan menggunakan form online sebagai medianya. Teknik samplingnya penggunakan purposive sampling yaitu mengambil sampling dari dosen, staf administrasi dan mahasiswa yang merupakan informan key dalam penelitian ini.

\section{HASIL DAN PEMBAHASAN}

Pada bagian ini akan diuraikan mengenai hasil dari metodologi yang telah dilakukan yakni hasil dari pengumpulan data yang telah dilakukan, analisis diskriptif tentang data responden dan juga analisis data. 


\subsection{Populasi dan Sampel}

Populasi yang digunakan dalam studi ini adalah pengguna SIAKAD pada beberapa Perguruan Tinggi Swasta di Jawa Tengah yang mayoritas dari Surakarta, yang terdiri dari mahasiswa, dosen, staft akademik, administrasi, serta pada bagian IT. Sampel yang diperoleh untuk pengujian dan analisis data yakni 147 orang yang mayoritas berasal dari Kota Surakarta, Jawa Tengah. Bedasarkan pekerjaanya/aktifitas nya saat ini meliputi: mahasiswa 100 orang, Dosen 31 orang, Pengelola/admin/operator SIA 12 orang dan programmer 4 orang, tersaji pada tabel 2. Sedangkan berdasarkan asal kota/ wilayah tempatnya bekerja meliputi dari Surakarta 138 orang, Pekalongan dan Banyumas masing-masing 2 orang, dan Semarang, Boyolali, Cilacap, Purwokerto dan Sragen masing-masing 1 orang, tersaji pada tabel 3. .

Tabel 2. Demografi responden berdasarkan pekerjaan

\begin{tabular}{lll}
\hline No & Aktifitas Pekerjaan & Jumlah responden \\
\hline $\mathbf{1}$ & Pengembang / Programer Sistem Informasi Akademik & 4 \\
\hline $\mathbf{2}$ & Mahasiswa/i & 100 \\
\hline $\mathbf{3}$ & Dosen & 31 \\
\hline $\mathbf{4}$ & Pengelola Sistem Informasi Akademik pada Perguruan Tinggi & 6 \\
\hline $\mathbf{5}$ & Admin Sistem Informasi Akademik pada Perguruan TInggi & 3 \\
\hline $\mathbf{6}$ & Operator Sistem Informasi Akademik pada Perguruan Tinggi & 3 \\
Total & & $\mathbf{1 4 7}$ \\
\hline
\end{tabular}

Tabel 3. Demografi responden berdasarkan asal kota

\begin{tabular}{lll}
\hline $\mathbf{N o}$ & Asal Kota & Jumlah responden \\
\hline $\mathbf{1}$ & Surakarta & 138 \\
\hline $\mathbf{2}$ & Semarang & 1 \\
\hline $\mathbf{3}$ & Pekalongan & 2 \\
\hline $\mathbf{4}$ & Banyumas & 2 \\
$\mathbf{5}$ & Boyolali & 1 \\
\hline $\mathbf{6}$ & Cilacap & 1 \\
$\mathbf{7}$ & Purwokerto & 1 \\
\hline Total & & $\mathbf{1 4 7}$ \\
\hline
\end{tabular}

\subsection{Faktor Analisis dan Indikator}

Berdasarkan hasil observasi oleh peneliti , maka faktor analisis dan indikator yang akan digunakan adalah sebagai berikut pada tabel 4 .

Tabel 4 Faktor-faktor dan Indikator Penelitian

\begin{tabular}{|c|c|c|c|}
\hline No & Faktor-faktor & Indikator & Sumber \\
\hline \multirow[t]{4}{*}{1} & \multirow{4}{*}{$\begin{array}{l}\text { Kualitas Sistem Informasi } \\
\text { Akademik (SIAKAD) } \rightarrow \\
\text { Kualitas }\end{array}$} & $\begin{array}{l}\text { a. Fungsionalitas SIAKAD (fungsi siakad dapat membantu kinerja } \\
\text { organisasi dalam menvaiikan informasi) }\end{array}$ & \multirow[t]{4}{*}{ [10] } \\
\hline & & $\begin{array}{l}\text { Kehandalan SIAKAD (Performa SIAKAD mampu menjalankan } \\
\text { kinerja organisasi dalam mewakili administrasi akademik) }\end{array}$ & \\
\hline & & $\begin{array}{l}\text { Kemudahan penggunaan SIAKAD (SIAKAD sangat mudah } \\
\text { dijalankan untuk mencari seputar informasi akademik) }\end{array}$ & \\
\hline & & $\begin{array}{l}\text { Aksesibilitas SIAKAD (SIAKAD dapat diakses melalui jaringan } \\
\text { internet dan dapat diakses melalui berbagai perangkat) }\end{array}$ & \\
\hline \multirow[t]{2}{*}{2} & \multirow[t]{2}{*}{$\begin{array}{l}\text { Kualitas } \quad \text { Informasi } \\
\text { SIAKAD } \rightarrow \text { Informasi }\end{array}$} & $\begin{array}{l}\text { Tingkat informatif SIAKAD (SIAKAD memberikan informasi yang } \\
\text { dibutuhkan oleh pengguna seputar informasi akademik) }\end{array}$ & \multirow[t]{2}{*}{ [10] } \\
\hline & & $\begin{array}{l}\text { Relevansi atau kemampuan SIAKAD dalam memberikan } \\
\text { informasi (informasi yang disajikan oleh SIAKAD sangat relevan } \\
\text { dan dijamin integritasnya) }\end{array}$ & \\
\hline \multirow[t]{2}{*}{3} & \multirow{2}{*}{$\begin{array}{l}\text { Keamanan Data/Informasi } \\
\text { pada SIAKAD } \rightarrow \\
\text { Keamanan }\end{array}$} & $\begin{array}{l}\text { Keamanan informasi dapat mengurangi insiden keamanan di } \\
\text { organisasi }\end{array}$ & \multirow[t]{2}{*}{ [11] } \\
\hline & & Keamanan informasi dapat melindungi data organisasi. & \\
\hline
\end{tabular}


c. Keamanan informasi dapat menghindari akses yang tidak sah.

\begin{tabular}{|c|c|c|c|c|c|}
\hline \multirow[t]{4}{*}{4} & \multirow{4}{*}{\multicolumn{2}{|c|}{$\begin{array}{l}\text { Penanganan } \\
\text { Keamanan } \\
\text { Penanganan }\end{array}$}} & a. & $\begin{array}{l}\text { Kerahasiaan informasi (mengubah kata sandi secara teratur } \\
\text { efektif untuk menghindari akses yang tidak sah) }\end{array}$ & \multirow[t]{4}{*}{ [11] } \\
\hline & & & b. & $\begin{array}{l}\text { menggunakan anti-virus secara teratur dapat melindungi } \\
\text { data/sistem.. }\end{array}$ & \\
\hline & & & c. & $\begin{array}{l}\text { pembaruan anti-virus secara teratur dapat melindungi } \\
\text { data/sistem. }\end{array}$ & \\
\hline & & & d. & $\begin{array}{l}\text { memindai file dan perangkat sebelum menggunakannya dapat } \\
\text { melindungi data/sistem }\end{array}$ & \\
\hline \multirow[t]{3}{*}{$\mathbf{5}$} & Kepuasan & Pengguna & a. & Akurasi SIAKAD (SIAKAD memberikan data yang akurat) & \multirow[t]{3}{*}{ [10] } \\
\hline & \multirow{2}{*}{\multicolumn{2}{|c|}{ SIAKAD $\rightarrow$ Kepuasan }} & b. & $\begin{array}{l}\text { Kelengkapan isi dari modul SIAKAD (modul SIAKAD berisi } \\
\text { informasi yang mewakili dalam kegiatan administrasi akademik) }\end{array}$ & \\
\hline & & & c. & $\begin{array}{l}\text { Format penyajian data (penyajian data SIAKAD mudah untuk } \\
\text { dipahami oleh pengguna) }\end{array}$ & \\
\hline
\end{tabular}

3.2 Analisis Data

\subsubsection{Hasil Penelitian}

Seluruh data kuisioner dari 147 responden yang diperoleh kemudian dianalisis menggunakan metose S3C-Latent dan digambarkan dalam stability graph pada Gambar 2 berikut :

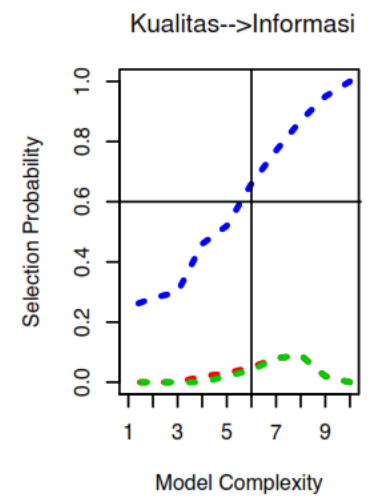

( a )

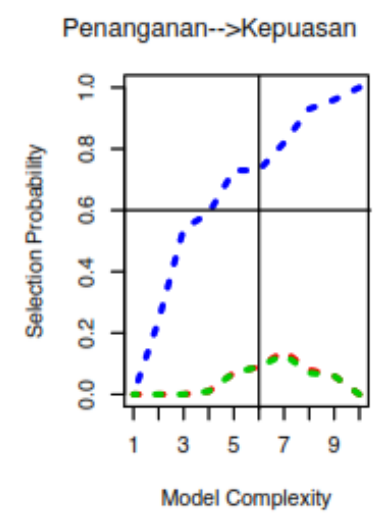

(e)

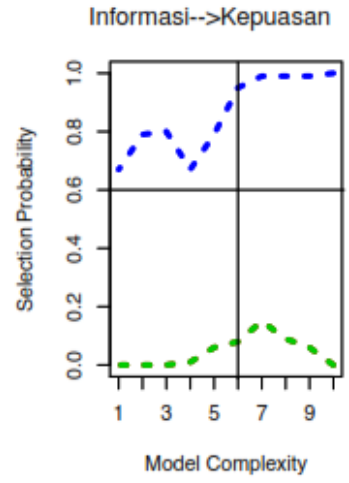

(b)

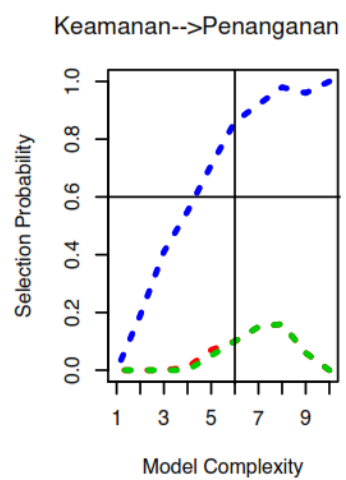

(c)

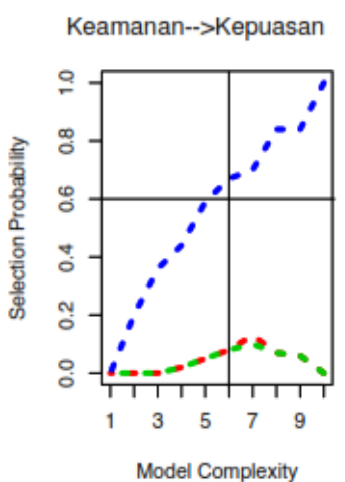

(d)

\begin{tabular}{|ll|}
\hline Variabel Kualitas & $=$ Kualitas Sistem Informasi Akademik \\
Variabel Informasi & $=$ Kualitas Informasi \\
Variabel Keamanan & $=$ Keamanan Data / Informasi \\
Variabel Penanganan & $=$ Penanganan pada masalah keamanan \\
Variabel Kepuasan & $=$ Kepuasan pengguna pada Layanan \\
$----\quad=$ edge stability & \\
- causal path stability \\
- any length
\end{tabular}

\section{Gambar 2. Stability graph}

Gambar 2 merupakan graph yang diperoleh dari hasil komputasi dataset yang digunakan dalam penelitian ini. Untuk memperoleh set yang paling stabil (stable variables) kami menggunakan batas ambang (threshold) dimana nilai threshold dari selection probability adalah 0.6 dan nilai threshold dari model complexity ditemukan pada kompleksitas model 5 . 
Sehingga dari Gambar 2 menunjukan bahwa tidak ditemukan adanya hubungan kausal antar variabel, namun ditemukan adanya hubungan asosiasi yang kuat yang tidak bisa ditentukan arah hubungan kausalnya. Hal ini dapat dilihat dari graph bahwa yang memenuhi kriteria threshold digambarkan dengan menggunakan garis warna biru ( --- ) yang menunjukan adanya hubungan asosiasi antar variabel tersebut, sedangkan garis warna hijau (--- ) yang menunjukan ada hubungan kausal tidak memenuhi nilai threshold yang telah ditentukan.

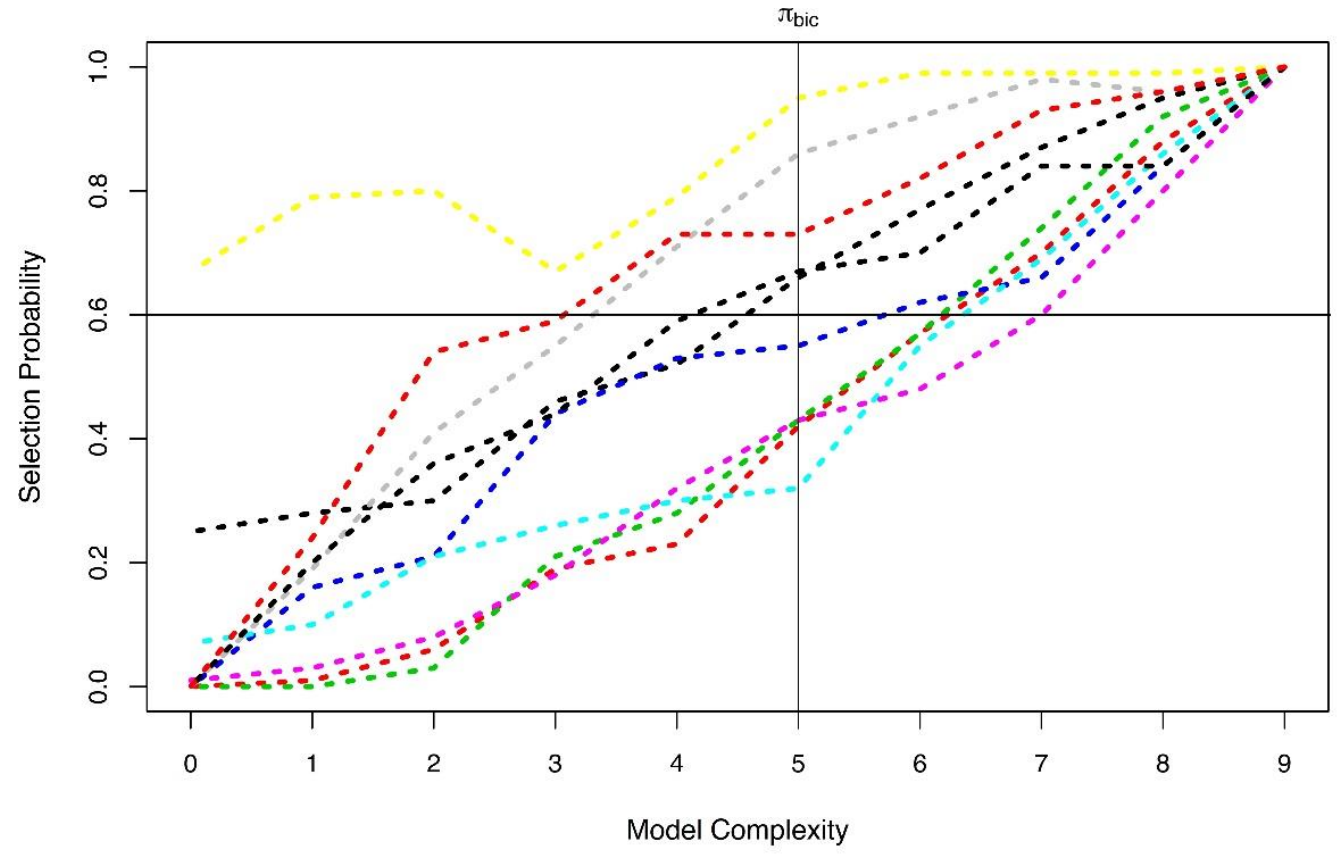

Gambar 3. edge stability graph

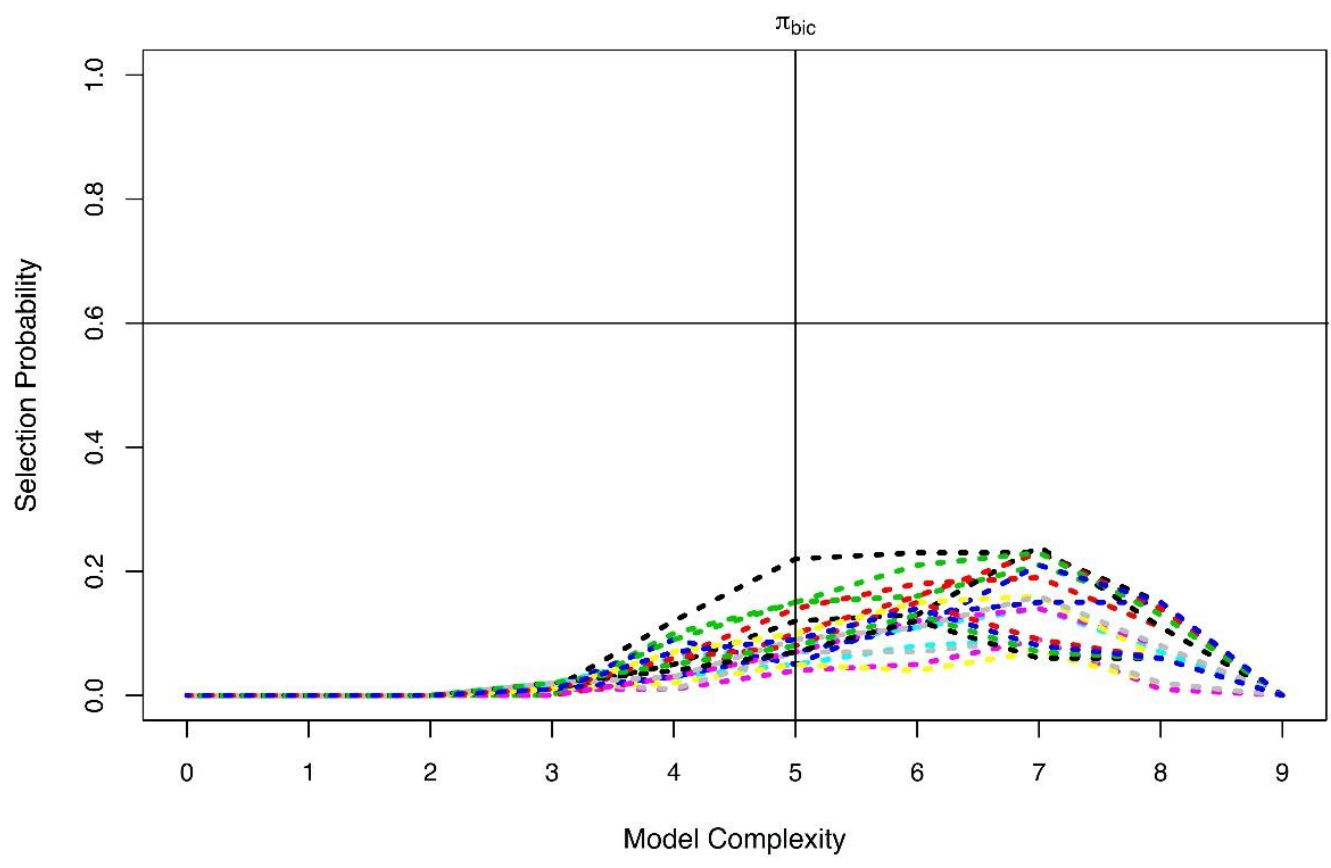

Gambar 4. Causal Path Stability Graph

Gambar 3 dan Gambar 4 menampilkan edge stability dan Causal Path Stability dengan $\boldsymbol{л}_{\mathrm{Sel}}=0.6$ dan $\boldsymbol{л}_{\text {bicl }}=5$. Setiap baris menunjukkan frekuensi hubungan antara sepasang variabel yang disebut model complexity, frekuensi (selection probability) dihitung dari jumlah yang muncul dalam setiap kompleksitas model. Causal path stability memperhitungkan 
hubungan kausal dalam jumlah dan frekuensi tertentu, sedangka edge stability memperhitungkan semua hubungan tanpa memandang arah hubungan yang terjadi.

Selanjutnya dari seluruh graph yang dihasilkan diatas kami menggambarkan struktur hubungan antar variable kedalam diagram sebagaimana pada Gambar 5 .

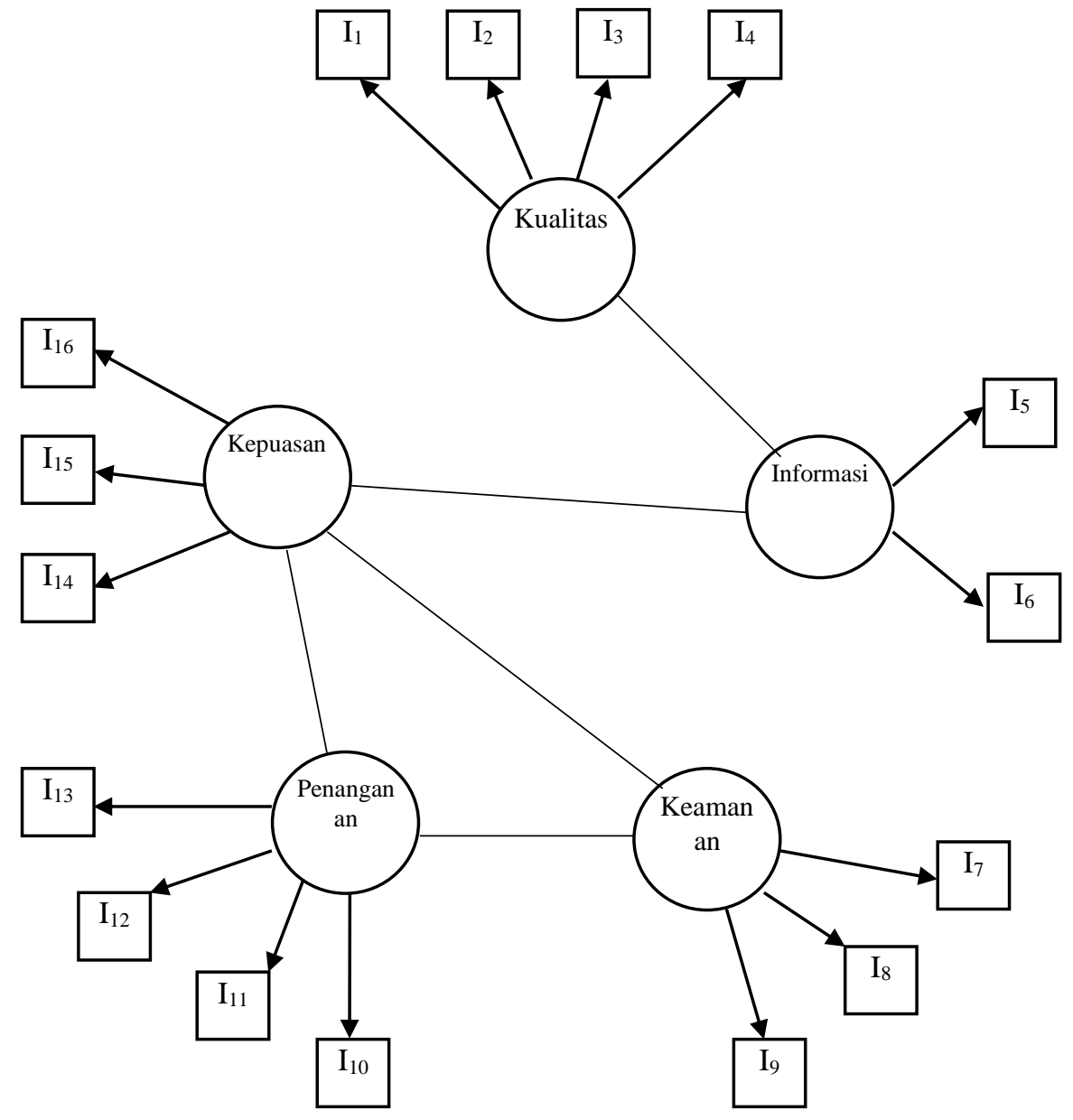

Gambar 5. diagram pemodelan kausal

Gambar 5 merupakan diagram yang memodelkan hasil dari hubungan antar variabel, bahwa setiap hubungan yang dimodelkan dalam graph pada Gambar 2 dan diidentifikasikan memenuhi syarat dihubungkan kedalam suatu model. Untuk selanjutnya model ini akan dibahas pada bagian 3.2.2. secara lebih rinci.

\subsubsection{Pembahasan}

Berdasarkan pada gambar Gambar 5 tidak ditemukan hubungan kausal antar variabel namun ditemukan adanya hubungan asosiasi yang kuat. Variabel kualitas sebagai variabel inti mempunyai hubungan secara langsung dengan variabel informasi. Dalam studi yang dilakukan oleh [12] dijelaskan bahwa kualitas sistem informasi yang baik berpengaruh signifikan terhadap hasil kualitas informasinya. Menurutnya [13] kualitas informasi merupakan faktor penting dalam keberhasilan SI dalam suatu manajemen organisasi. Secara tidak langsung variabel kualitas juga berhubungan dengan variabel kepuasan yang mana variabel ini saling berhubungan dengan variabel keamanan dan variabel penanganan keamanan. Adapun indikator yang mempengaruhi faktor-faktor dijelaskan dalam Tabel 4 yang pada Gambar 5 kami tulis dengan kode $\left\{l_{1}, \ldots, l_{16}\right\}$ secara berurutan.

Dalam studi lain yang masih berkaitan dengan [14] sistem informasi [15] menyampaikan bahwa kualitas sistem adalah pengukuran proses sistem informasi yang berfokus pada hasil interaksi antara pengguna dan sistem. Kualitas sistem mempunyai atribut-atribut seperti ketersediaan peralatan, reliabilitas peralatan, kemudahan untuk digunakan, dan waktu respon merupakan faktor penentu mengapa sebuah sistem informasi digunakan atau tidak digunakan. Dalam artikelnya bahwa sesuai dengan hasil penelitian ini bahwa kualitas sistem berhubungan dengan variabel-variabel lain yang ditetapkan dalam penelitian ini. 
Hal ini sesuai dengan apa yang disampaikan [16] dalam artikelnya bahwa kualitas informasi adalah faktor penting dari suatu sistem informasi. Misalnya relevansi, pengertian, akurasi, kelengkapan, ketepatan waktu, kegunaan. Output dari sistem informasi harus relevan dengan tujuan yang diperlukan, mudah dipahami, akurat, singkat, lengkap atau berisi semua informasi yang diperlukan, dan tepat waktu untuk mendukung kebutuhan informasi, dan kegunaan. Menurut [13] Sejumlah peneliti menganggap kualitas informasi sebagai faktor penting untuk keberhasilan SIM dalam organisasi.

Dalam studi [12], [17] menjelaskan bahwa hubungan antara variabel informasi dengan kepuasan yaitu kualitas informasi merupakan faktor penting dalam menentukan kepuasan pengguna, bahkan inti dasar dari sistem informasi adalah mengelola informasi dan memberikan informasi kepada penggunanya. Kualitas informasi sebagai output dari sistem informasi adalah salah satu komponen utama yang menjadi faktor kepuasan pengguna. Sebagaimana ditunjukan pada Gambar 5 bahwa Variabel Kepuasan saling berhubungan dengan dua variabel lainya yaitu Variabel keamanan dan Variabel penanganan. Dalam artikel yang ditulis oleh [18] bahwa suatu sistem yang terhubung dengan internet sangat rentan terhadap resiko keamananya, sehingga sangat memungkinkan terjadinya kerusakan atau bahkan kehilangan data. [19] menjelaskan bahwa keamanan informasi yang baik tergantung pada perilaku pengguna saat menggunakan sistem informasi. Kepuasan pengguna banyak digunakan untuk mengukur keberhasilan sistem informasi dalam menjamin keamanan informasi.Serupa dengan sistem informasi yang lain (misalnya, sistem informasi akuntansi), dalam artikelnya [20] yang meneliti terkait kualitas sistem informasi, bahwa kualitas informasi ini menjadi salah satu faktor penting yang berhubungan langsung dengan kepuasan pengguna dalam sistem informasi.Dalam artikelnya [21] menyatakan bahwa salah satu fungsi utama dari sistem keamanan termasuk dalam penanganan masalah keamanan sistem adalah proses otentikasi sangat penting untuk mengendalikan akses ke berbagai sumber daya dan fasilitas. Otentikasi pengguna adalah titik awal masuk ke layanan sistem untuk memperoleh akses.

Hubungan asosiasi yang terjadi antara variabel kualitas dengan variabel informasi sesuai dengan penelitianpenelitian sebelumnya yang menyatakan bahwa antar kedua variabel ini tidak dapat dipisahkan, karena sesuai dengan namanya bahwa sistem informasi sendiri memiliki fungsi utama untuk mengelola serta menjaga kualitas informasi yang ada didalamnya.

Sesuai dengan penelitian [10] bahwa dalam menjaga keamanan informasi, pengguna sistem informasi akademik secara berkala dapat merubah password dan memiliki kombinasi angka, huruf, ataupun simbol dengan panjang minimal 8 karakter agar password sulit dicuri oleh orang lain, serta dalam pengembangan dan pemeliharaan sistem informasi perlu adanya prosedur untuk memeriksa keabsahan dari penggunaan sistem informasi akademik dari kerusakan ataupun kesalahan pengolahan data. Dalam artikel lain tentang Quality of mobile information services [22] menjelaskan bahwa kualitas informasi juga menjadi faktor yang berhubungan erat dengan kepuasan pengguna.

Dari beberapa penelitian diatas, berarti bahwa hubungan asosiasi yang secara langsung terjadi antara kualitas informasi dengan variabel kepuasan pengguna relevan dengan penelitian-penelitian sebelumnya. Dan sebagaimana dengan artikel [23] bahwa dalam implementasinya kualitas sistem informasi yang baik akan berdampak pada kepuasan pengguna.

Variabel lain yang berhubungan langsung dengan variabel informasi adalah variable keamanan informasi dan variabel penanganan. Dalam buku yang ditulis oleh [24] menjelaskan bahwa keamanan informasiakan mencakup beberapa implikasi salah satunya adalah mengatasi risiko dan memaksimalkan manfaat bagi penggunanya, yang mana dapat kita ketahui bahwa dengan sistem yang dijamin keamanan informasinya, maka secara langsung pengguna akan merasa tenang dan menikmati penggunaan layanan tersebut. Sebaliknya [25] menjelaskan bahwa pengguna yang sering dianggap sebagai mata rantai terlemah dalam masalah keamanan informasi, juga dapat menjadi aset besar dalam menanggulangi masalah terkait risiko keamanan informasi. Hal ini terjadi apabila pengguna mematuhi aturan keamanan yang diberlakukan dalam suatu sistem informasi. Artikel ini juga menjelaskan terkait bagaimana keamanan informasi ini juga berkaitan erat dengan bagaimana penanggulangan masalah keamanan dilakukan baik oleh sistem maupun oleh pengguna.

Dalam penelitian ini hubungan antar variabel digambarkan sebagai hubungan asosiasi yang kuat sebagaimana pada Gambar 5 yang tidak bisa ditentukan arah hubungan kausalnya. Namun secara keseluruhan, semua variabel saling berhubungan, baik secara langsung maupun tidak langsung. Variabel kualitas secara langsung berhubungan dengan variabel informasi, yang mana Variabel Informasi secara langsung terhubung dengan variabel kepuasan pengguna. Tiga variabel yaitu variabel kepuasan pengguna, variabel keamanan dan variabel penanganan masalah keamanan, ketiganya saling berhubungan secara langung yang artinya ketiganya memiliki hubungan asosiasi yang kuat.

Variabel-variabel yang ada ini tentunya dipengaruhi oleh indikator-indikator yang ada sebagaimana pada gambar Gambar 5 bahwa secara langsung Variabel kualitas sistem dipengaruhi oleh empat indikator $I_{1}, l_{2}, l_{3}, l_{4}$ yakni Fungsionalitas SIAKAD sebagai $l_{1}$, Kehandalan SIAKAD sebagai $l_{2}$, Kemudahan penggunaan SIAKAD sebagai $l_{3}$ dan Aksesibilitas SIAKAD sebagai $I_{4}$. Variabel informasi dipengaruhi oleh dua indikator $I_{5}$, $I_{6}$ yakni tingkat informatif SIAKAD sebagai $I_{5}$ dan Relevansi SIAKAD dalam memberikan informasi sebagai $I_{6}$. Variabel Keamanan Informasi dipengaruhi 
oleh tiga indikator $l_{7}, l_{8}, l_{9}$ yakni Keamanan informasi dapat mengurangi insiden keamanan di organisasi sebagai $l_{7}$, keamanan informasi dapat melindungi data organisasi sebagai $l_{8}$, dan keamanan informasi dapat menghindari akses yang tidak sah sebagai $l_{g}$. Variabel penanganan dipengaruhi oleh empat indikator $I_{10}, l_{11}, l_{12}, l_{13}$ yakni Kerahasiaan informasi sebagai $I_{10}$, menggunakan anti-virus secara teratur sebagai $I_{11}$, melakukan update anti-virus secara teratur sebagai $I_{12}$, dan memindai file dan perangkat sebelum menggunakannya sebagai $I_{13}$. dan variabel kepuasan pengguna dipengaruhi oleh tiga indikator $I_{14}, I_{15}, I_{16}$ yakni akurasi SIAKAD sebagai $I_{14}$, kelengkapan SIAKAD dalam menyajikan data/informasi sebagai $I_{15}$, dan format dalam penyajian data/informasi sebagai $I_{16}$.

Pada penelitian ini menggali informasi dengan menggunakan lima variabel dan 16 indikator ini dengan menggunakan metode Stable Spesification Search for Cross-Sectional Data with Latent Variable (S3C-Latent)yang dikembangkan oleh [6] sejalan dengan penelitian-penelitian yang telah dilakukan sebelumnya dengan menggunakan berbagai metode yang berbeda.

\section{KESIMPULAN}

\subsection{Kesimpulan}

Berdasarkan hasil dan proses analisis yang dilakukan dalam studi ini, maka dapat ditarik kesimpulan bahwa ditemukan adanya hubungan asosiasi yang kuat antar variabel yang tidak bisa ditentukan arah hubungan kausalnya. Kualitas sistem informasi sebagai variabel inti berhubungan langsung dengan variabel kualitas informasi dan semua variabel mempunyai hubungan asosiasi, baik secara langsung maupun tidak langsung. Secara tidak langsung variabel kualitas sistem informasi melalui variabel kualitas informasi mempunyai hubungan dengan variabel kepuasan pengguna, yang mana variabel kepuasan pengguna berhubungan dengan dua variabel lainya yaitu variabel keamanan dan variabel penanganan sistem terhadap masalah keamanan.

\subsection{Saran}

Berdasarkan keterbatasan yang muncul dalam studi ini, maka saran untuk pengembangan penelitian selanjutnya adalah dii masa yang akan datang untuk menyempurnakan penelitian ini, proses penggalian data melalui kuisioner untuk dapat ditingkatkan baik kuantitas maupun kualitas kuisioner nya untuk memperoleh hasil yang lebih baik, dengan jumlah data yang lebih banyak, diharapkan akan muncul hubungan kausal antar variabel nya.

Metode Stable Spesification Search for Cross-Sectional Data with Latent Variable (S3C-Latent) adalah metode baru yang dikembangkan oleh [1] yang sangat memungkinkan untuk di eksplorasi lebih jauh untuk mencari hubungan kausal antar faktor.

\section{UCAPAN TERIMA KASIH}

Peneliti secara khusus mengucapkan terima kasih yang sebesar-besarnya kepada semua pihak yang telah membantu, lebih khusus kepada Bapak Dr. Ing. Ridho Rahmadi selaku pembimbing, yang melalui karya beliau package S3C-Latent yang dapat diakses pada https://github.com/rahmarid/S3C-Latent dan diimplementasikan kedalam bahasa Pemrograman R. Peneliti banyak menerima bimbingan, petunjuk dan bantuan serta dorongan dari berbagai pihak baik yang bersifat moral maupun material.

\section{DAFTAR PUSTAKA}

[1] R. Rahmadi, P. Groot, and T. Heskes, "Stable Specification Search in Structural Equation Models with Latent Variables," ACM Trans. Intell. Syst. Technol., vol. 10, no. 5, 2019.

[2] D. Ahmad Jakaria, R. Teduh Dirgahayu, and Hendrik, "Manajemen Risiko Sistem Informasi Akademik pada Perguruan Tinggi Menggunakan Metoda Octave Allegro," Semin. Nas. Apl. Teknol. Inf., vol. 37, pp. 1907-5022, 2013.

[3] N. U. Handayani, M. A. Wibowo, D. P. Sari, and Y. Satria, "Penilaian Risiko Sistem Informasi Fakultas Teknik Universitas Diponegoro Menggunakan Metode Failure Mode Effect And Analysis Berbasis Framework ISO 27001," vol. 39, no. 2, pp. 78-85, 2018.

[4] B. Rahardjo, Keamanan Sistem Informasi Berbasis Internet. PT Insan Infonesia Bandung \& PT INDOCISC Jakarta, 2002.

[5] R. Rahmadi, P. Groot, M. Heins, H. Knoop, T. Heskes, and T. Optimistic, "Causality on cross-sectional data : Stable specification search in constrained structural equation modeling," Appl. Soft Comput., vol. 52, pp. 687698, 2017.

[6] R. Rahmadi, P. Groot, and T. 0. M. Heskes, "Stable Specification Search in Structural Equation Models with Latent Variables," ACM Trans, Intell. Syst. Technol, vol. 10, no. 5, 2019.

[7] R. Rahmadi, Finding Stable Causal Structures From Clinical Data. Enschede: Gildeprint, 2019. 
[8] Ucu Nugraha, "Manajemen Risiko Sistem Informasi Pada Perguruan Perguruan Tinggi Menggunakan Kerangka Kerja NIST SP 800-300," Semin. Nas. Telekomun. dan Inform. (SELISIK 2016), no. Selisik, pp. 2503-2844, 2016.

[9] I. Desy, B. Cahyo Hidayanto, and H. Maria Astuti, "Penilaian Risiko Keamanan Informasi Menggunakan Metode Failure Mode and Effects Analysis Di Divisi Ti Pt. Bank Xyz Surabaya," Semin. Nas. Sist. Inf. Indones., vol. 22, no. September, 2014.

[10] E. Kurniawan and I. Riadi, "Analisis Tingkat Keamanan Sistem Informasi Akademik Berdasarkan Standar ISO 27002 : 2013 Menggunakan SSE-CMM," vol. 2, no. 1, pp. 12-23, 2018.

[11] N. Humaidi and V. Balakrishnan, "Exploratory Factor Analysis of User's Compliance Behaviour towards Health Information System's Security," J. Heal. Med. Informatics, vol. 4, no. 2, 2013.

[12] Y. H. Al-mamary, A. Shamsuddin, and N. Aziati, "The Relationship between System Quality , Information Quality, and The Relationship between System Quality , Information Quality , and Organizational Performance," Int. J. Knowl. Res. Manag. E-Commerce, vol. 4, no. 3, July 2014, 2014.

[13] Y. Al-Mamary, A. Shamsuddin, and N. Abdul Hamid, "Key factors enhancing acceptance of management information systems in Yemeni companies," J. Bus. Manag. Res., vol. 5, no. August, pp. 108-111, 2014.

[14] B. D. Weinberg, "Don't Keep Your Internet Customers Waiting Too Long at the (Virtual) Front Door," J. Interact. Mark., vol. 14, p. 30, 2000.

[15] S. Pawirosumarto, "PENGARUH KUALITAS SISTEM, KUALITAS INFORMASI, DAN KUALITAS LAYANAN TERHADAP KEPUASAN PENGGUNA SISTEM E-LEARNING," J. IIm. Manaj., vol. 6, no. 3, 2016.

[16] S. Petter, W. Delone, and E. McLean, "Measuring information systems success: Models, dimensions, measures, and interrelationships," EJIS, vol. 17, pp. 236-263, 2008.

[17] S. Laumer, C. Maier, and T. Weitzel, "Information quality, user satisfaction, and the manifestation of workarounds: a qualitative and quantitative study of enterprise content management system users," Eur. J. Inf. Syst., vol. 26, no. 4, pp. 333-360, Jul. 2017.

[18] F. Farahmand, S. Navathe, P. Jr, and G. Sharp, "Managing vulnerabilities of information systems to security incidents," 2003, pp. 348-354.

[19] G. P. Z. Montesdioca and A. C. G. Macada, "ScienceDirect Measuring user satisfaction with information security practices," Comput. Secur., vol. 8, 2015.

[20] N. Nirwanto and M. Andarwati, "End-user Satisfaction as an Impact of the System Quality, Information Quality, and Top Management Support, upon the Perceived Usefulness of Technology Utilization," 2019.

[21] C. Braz and J.-M. Robert, "Security and usability: the case of the user authentication methods.," 2006, pp. 199203.

[22] T. Koivumäki, A. Ristola, and M. Kesti, "The effects of information quality of mobile information services on user satisfaction and service acceptance-empirical evidence from Finland," Behav. Inf. Technol., vol. 27, no. 5, pp. 375-385, 2008.

[23] V. Ribiere, A. J. LaSalle, R. Khorramshahgol, and Y. Gousty, "Hospital information systems quality: a customer satisfaction assessment tool," in Proceedings of the 32nd Annual Hawaii International Conference on Systems Sciences. 1999. HICSS-32. Abstracts and CD-ROM of Full Papers, 1999, vol. Track4, p. 7 pp.

[24] D. Catteddu, "Cloud Computing: Benefits, Risks and Recommendations for Information Security," in Web Application Security, 2010, p. 17.

[25] B. Bulgurcu, H. Cavusoglu, and I. Benbasat, "Information Security Policy Compliance: An Empirical Study of Rationality-based Beliefs and Information Security Awareness," MIS Q., vol. 34, no. 3, pp. 523-548, Sep. 2010. 